\title{
Evaluating the validity of rice straw as a suitable agricultural substrate for common bean plants under net house conditions
}

\author{
Ahmed Mohamed Said, Moursy Fatma Sayed and Sadek Ihab Ibrahim * \\ Central Laboratory for Agricultural Climate (CLAC), Agricultural Research Center (ARC), Giza, Egypt. \\ Publication history: Received on 14 January 2020; revised on 23 January 2020; accepted on 27 January 2020
}

Article DOI: https://doi.org/10.30574/gscarr.2020.2.1.0002

\begin{abstract}
This research paper was carried out in the net house at the Central Laboratory for Agricultural Climate (CLAC), throughout two tested seasons of 2017/2018 and 2018/2019 to investigate the effect of using rice straw as a growing substrate (bale \& ditch) on vegetative growth, yield and water use efficiency (WUE) of two cultivars of common bean (Phaseolus vulgaris L.), Hilda as indeterminate variety and Nebraska determinate variety compared to conventional cultivation in soil. Seedlings were cultivated at $1^{\text {st }}$ September in two growing seasons. Study was included three treatments with 4 replicates arranged in a randomized complete block design. Results indicated that plants grown on ditch rice straw treatment as substrate reflected the highest positive effect on vegetative growth characters (plant length, number of leaves/plant and stem diameter), leaves mineral content of N. P. K and yield and its components (total yield/plant, and fiber content on pods) at both studied cultivars. While, the lowest negative effect on those characters was observed with bale rice straw treatment. Moreover, raised bed clay (control) treatment was replaced in second place after the treatment of ditch rice straw. In addition, cultivation into straw ditch consumed lower quantities of water than other treatments. Finally, straw ditch substrate may be recommended for increasing common bean productivity and decreasing water utilization beneath net house conditions.
\end{abstract}

Keywords: Common bean; rice straw; net house; water consumption

\section{Introduction}

Common bean (Phaseolus vulgaris L.) is one of the foremost vital vegetable crops developed in all landmasses of the world, it's characterized with high protein, fiber, and complex carbohydrate substance [1]. A great developing media ought to have a few characteristics such as to supply air circulation and water, permit for greatest root development and bolster physically the plant [2].

On other hand, the foremost critical issues confronting common bean generation in Egypt is soil-borne pathogens, nematodes and soil saltiness. Agrarian squanders incorporate straw, stubble, takes off, buildups from cereal crops and corn cobs and tree appendages from crops and plantations [3] are among the causes of natural contamination.

Burning straw causes creating numerous destructive substances, such as sulfur dioxide, silicon dioxide and inhalable particles, which are transmitted into the atmosphere [4]. Rice straw represents an imperative summer trim by-product in Egypt. Almost 5 million tons of rice straw is delivered each year from the rice cultivated areas. No organized recycling process were utilized for this squander until presently. In addition, it causes genuine contamination when arranged by burning [5]. Change straw into valuable items may ameliorate the issues. Within the final decades, burning as a transfer strategy for getting off straw is being decreased and more of rice straw is being utilized. The huge amounts of rice straw that delivered in Egypt (more than 5 million tons each year), the very cheap cost and the components of rice straw

\footnotetext{
* Corresponding author

E-mail address: dr.ihabsadek@yahoo.com
} 
(silica, lignin and hemicelluloses), which are not alluring or favorable for soil parasites or nematodes, it seem speak to a good substrate for sowing rather than characteristic soil troubles beneath open field conditions [5]. The development of cucumber plants was more productive in straw medium than within the soil [6]. Similarly, [5] expressed that strawberry plants developed on rice straw bunches had greater vegetative development, roots fresh weigh as compared with those developed in characteristic soil.

Therefore, the objective of the present work was to evaluate the validity of rice straw as a suitable agricultural media (substrate) for common bean plants under net house conditions. To present the most suitable method of cultivating common bean in rice straw (bale or ditch).

\section{Material and methods}

\subsection{Experimental layout}

The experiment was conducted during the autumn growing seasons of 2017/2018 and 2018/2019 at the experimental farm of Dokki site, Central Laboratory for Agricultural Climate (CLAC), Agricultural Research Center (ARC), Giza. Two cultivars of common beans (Phaseolus vulgaris L.) were used i.e., Nebraska as determinate variety and Hilda as indeterminate variety. Seedling for each cultivar was transplanted on $1^{\text {st }}$ of September in both growing seasons under net house. The distance between rows was $0.50 \mathrm{~m}$ and between plants was $0.30 \mathrm{~m}$. The total area of net house was 360 $\mathrm{m}^{2}$ (9 $\mathrm{m}$ width $\mathrm{x} 40 \mathrm{~m}$ length).

\subsection{Greenhouse preparation}

The area of net house was divided into equal five lines; the area of each line was $40 \mathrm{~m}^{2}$ (1m width $\mathrm{x} 40 \mathrm{~m}$ length). Four parts were dig $0.50 \mathrm{~m}$ depth to create ditches. All of the four ditches have been covered by black plastic mulch, to prevent the effect of the soil on plant roots. Two of these ditches filled by separated rice straw and the other two ditches filled by arranged rice straw bales. The fifth part was leaved to make raised bed as a control treatment. Recommended amount of fertilizer (17 Kg of calcium super phosphate, $4.5 \mathrm{Kg}$ of ammonium sulphaet, $8.5 \mathrm{Kg}$ of sulpher, $4.5 \mathrm{Kg}$ of potassium sulphate and $2 \mathrm{~m}^{3}$ of compost) were mixed perfectly to create a starter. Such mix was divided into equal five quantities. One of last mentioned mix quantity was added to each of the four ditches and the soil raised bed two weeks before transplanting [7].

The chemical analysis of the soil and the rice straw were estimated according to [8]. Physical and chemical characteristics were shown in Tables (1 and 2), respectively.

Table 1 The physical and chemical characteristics of experimental site soil.

\begin{tabular}{|c|c|c|c|c|c|c|c|c|c|c|c|c|c|}
\hline \multicolumn{2}{|c|}{$\begin{array}{l}\text { Particle } \\
\text { distribution }\end{array}$} & \multirow{2}{*}{$\begin{array}{l}\text { size } \\
\text { Clay }\end{array}$} & \multirow{2}{*}{$\begin{array}{l}\text { Texture } \\
\begin{array}{l}\text { Sandy } \\
\text { clay }\end{array}\end{array}$} & \multirow{2}{*}{$\begin{array}{l}\mathbf{P H} \\
1: 2.5\end{array}$} & \multirow{2}{*}{$\begin{array}{l}\text { EC } \\
\mathrm{dS} / \mathrm{m}\end{array}$} & \multirow{2}{*}{$\begin{array}{l}\text { Ca Co3 } \\
\%\end{array}$} & \multirow{2}{*}{$\begin{array}{l}\mathbf{O M} \\
\%\end{array}$} & \multicolumn{5}{|c|}{$\begin{array}{l}\text { Soluble } \\
(\mathrm{meq} / \mathrm{l})\end{array}$} & \multirow{2}{*}{$\begin{array}{l}\text { (soil paste ext.) } \\
\mathrm{HCO}^{-}-\end{array}$} \\
\hline Sand & Silt & & & & & & & $\mathrm{Ca}+$ & $\mathrm{Mg}++$ & $\mathrm{Na}+$ & $\mathrm{K}+$ & Cl- & \\
\hline 57.3 & 16.7 & 26 & $\begin{array}{l}\text { clay } \\
\text { loam }\end{array}$ & 2 & 2.4 & 16.0 & 0.35 & 6.0 & 3.0 & 20.1 & 1.2 & 13.0 & 2.6 \\
\hline
\end{tabular}

Table 2 The chemical characteristics of used rice straw.

\begin{tabular}{llllllllll}
\hline Moisture \% & C/N Ratio & EC dS/m & Ash \% & Protein \% & N \% & P \% & K \% & Cellulose \% & Lignin \% \\
\hline 8.4 & 61.25 & 2.3 & 19.3 & 5.3 & 0.8 & 0.6 & 0.4 & 35 & 12.2 \\
\hline
\end{tabular}

\subsection{Treatments}

Two types of rice straw were used as treatments. Ditches full of separated rice straw (ditch rice straw) was the first treatment. The second treatment was Ditches full of arranged rice straw bale (rice straw bale). Both of two treatments were compared to raise bed clay soil (control). 


\subsection{Growing season temperature profile}

Both of maximum and minimum temperatures were recorded daily during the all over period of growing seasons of the two tested cultivars. Two types of temperatures were recorded, (1) air temperature and (2) soil and substrate temperatures. Air temperature was recorded on daily bases inside and outside the net house. Also, temperature of soil and substrate (bale and ditch) were recorded. All values were collected and averaged every 10 days. Data was collected using meteorological station located inside the net house.

\subsection{Calculation of irrigation requirements}

Historical data for Class-A pan evaporation $\left(\mathrm{ET}_{\mathrm{p}}\right)$ values were provided from CLAC to calculate the irrigation requirements for common beans plants during both tested seasons.

Irrigation requirements for common beans were calculated based on crop evapotranspiration (ETo) and the evapotranspiration under net house conditions was estimated according to [9]. As follow:

$\mathrm{ET}_{\mathrm{GH}}=0.7 \times$ ETo

Where:

$\mathrm{ET}_{\mathrm{GH}}=$ the evapotranspiration under greenhouse conditions

ETo $=$ the evapotranspiration in the open field conditions

Drip irrigation system was used for irrigation which applied following the evapotranspiration (ETc) method according to soil water balance [10] as follows:

$\mathrm{ETc}=\mathrm{ET}_{\mathrm{GH}} \times \mathrm{Kc}$

Where:

$\mathrm{ETc}=$ the water requirements for common beans plant under greenhouse conditions

$\mathrm{ET}_{\mathrm{GH}}=$ the evapotranspiration under greenhouse conditions

$\mathrm{Kc}=$ the crop coefficient for common beans plant

The Kc of common beans plants was used according to [11]; the Kc values were varied throughout different plant growth stages and increased from 0.5 (initial stage) to 1.05 (middle stage) from transplanting to the begging of harvest, and decreased again from 1.09 to 0.95 at the end of the growing season. Drip irrigation was used from September $1^{\text {st }}$ up to the end of the growing season of different varieties, the growing season for Nebraska cultivar was from September $1^{\text {st }}$ to the end of December. Whereas, Hilda cultivar from September $1^{\text {st }}$ to the end of February. The total amount of irrigation water was estimated, different amount of irrigation water during both growing seasons are shown in Table 4 .

Table 3 Irrigation water consumption amount for Nebraska and Hilda cultivated area in both growing seasons.

\begin{tabular}{lll}
\hline Period & $\mathbf{2 0 1 7 - 2 0 1 8}$ & $\mathbf{2 0 1 8 - 2 0 1 9}$ \\
\hline 1-30 September & 1093.5 & 1093.5 \\
1-30 October & 904.1 & 904.1 \\
1-31 November & 1015.2 & 1015.2 \\
1-31 December & 1170.0 & 1170.0 \\
1-31 January & 1554.0 & 1554.0 \\
1-28 February & 2046.2 & 2046.2 \\
\hline Total consumption for Nebraska cultivar \\
\hline Total (L / plot) & 4182.8 & 4182.8 \\
Total (m³ plot) & 4.18 & 4.18 \\
Total (m³ GH) & 20.9 & 20.9 \\
\hline Total consumption for Hilda cultivar \\
\hline Total (L / plot) & 7783.0 & 7783.0 \\
Total (m 3 plot) & 7.8 & 7.8 \\
Total (m 3 / GH) & 39 & 39 \\
\hline
\end{tabular}




\subsection{Recorded Data}

A sample of three randomized common bean plants from each replicate in different treatments were collected (at the mid-season) after 60 days from transplanting for Nebraska cultivar and 90 days for Hilda cultivar, to determine the following characteristics i.e., plant length, number of leaves/plant, stem diameter, fresh and dry weight of (leaves, stem and total plant) and leaf area for fourth leaf from growth apical. In addition, pods number/plant for each treatment was estimated from the first harvest to the end of the season, after that, the total yield per plant was estimated.

The N, $\mathrm{P}$ and $\mathrm{K}$ content were determined in leaves samples after dried at $70{ }^{\circ} \mathrm{C}$ in an air forced oven for 24 hours. Dried leaves were digested in $\mathrm{H}_{2} \mathrm{SO}_{4}$, the fallowing mineral contents were estimated (phosphorous, potassium in the acid digested solution by colorimetric method, ammonium molybdate, by spectrophotometer and flame photometer [12]. Total nitrogen was determined by Kjeldahl method according to the procedure described by [13]. The total fiber content also estimated in green pods on dry weight basis according to [8].

\subsection{Water use efficiency (WUE)}

Water use efficiency was calculated for fresh yield of common beans pods for different treatments according to [14], using the following equation

WUE $=$ Total yield $(\mathrm{Kg}) /$ Total water consumption $\left(\mathrm{m}^{3}\right)$.

\subsection{Experimental design and data analysis}

Treatments were arranged in randomized complete blocks with four replications. Obtained data were statistically analyzed using the analysis of variance method. Duncan's multiple range tests at $5 \%$ level of probability were used to compare means of the treatments [15].

\section{Results}

Growing season's temperature profile

\subsection{Minimum temperature}

Data in Figure (1) clarify minimum air temperature outside and inside the net house, as well as, minimum soil and rice straw substrate (bale and ditch). From such data it was found that minimum air temperature inside the net house was higher than outside the net house all over the period of both studied seasons 2017/2018 and 2018/2019. In addition, from the Figure (1) it's clear during first 60 days of both growing seasons minimum air temperature was always higher than $20^{\circ} \mathrm{C}$, that is allow for both tested cultivars to grown strongly and gave a good vegetative growth.

After 60 days from transplanting until the end of the growing seasons, minimum air temperature continue to decrease to reach the lowest values at the day 140 and 150 during seasons of 2017/2018 and 2018/2019, respectively. Highest minimum air temperature were 24.72 and $26.00^{\circ} \mathrm{C}$, during $2017 / 2018$ and $2018 / 2019$ seasons, respectively.

Concerning soil and substrate minimum temperature, it was noticed that, soil temperature recorded higher values of minimum temperature compared to the bale and ditched rice straw during the first 50 days. From the day 60 to the end of the growing seasons ditched rice straw ranked the first and highest minimum temperature. Contrary, the bale rice straw was the lowest minimum temperature all over the growing seasons. The same trend was found during both studied seasons. This trend of minimum temperature within the tested substrate allow plants to make a strong root system and good nutrients uptake, and this is reflected in the trend of both vegetative growth and yield.

\subsection{Maximum temperature}

From data in Figure (2) it was concluded that, maximum air temperature was highest inside the net house compared to the outside net house all over the growing seasons which is create a favorable temperature conditions to growing the plants and reflected in good vegetative growth. Such trend of maximum air temperature distributions was true during both studied seasons.

Discussing soil and substrate maximum temperature, it was noticed that soil maximum temperature was the highest comparing to bale and ditched rice straw during the first 50 days. From the day 50 after transplanting to the end of the growing season ditch rice straw recorded highest values of maximum temperature during both studied seasons. Contrary, the bale rice straw was the lowest maximum temperature all over the growing seasons. The same trend was 
found during both studied seasons. This trend of maximum temperature within the tested substrate allows plants to make a strong root system and good nutrients uptake, and this is reflected in the trend of both vegetative growth and yield.

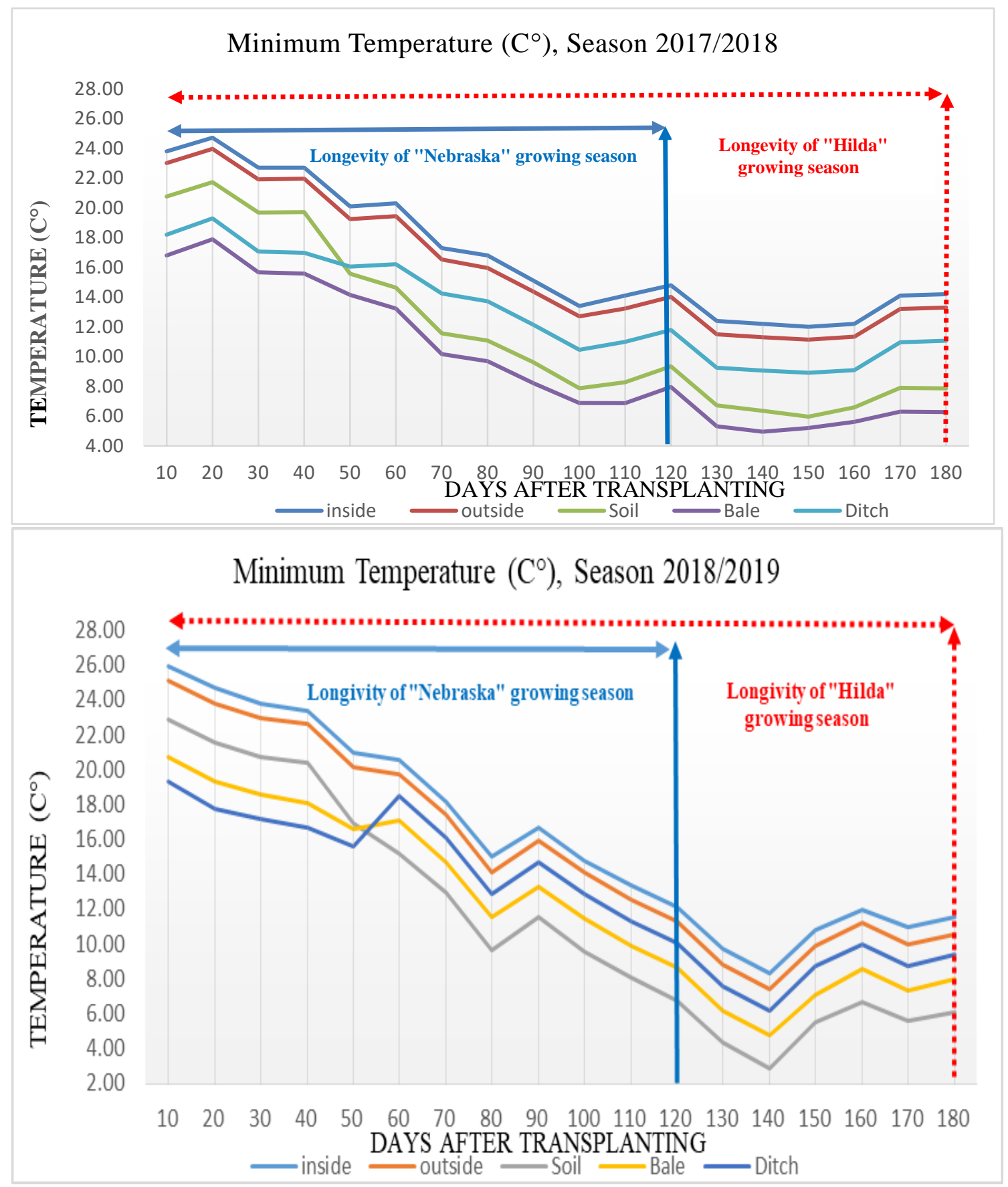

Figure 1 Minimum air temperature inside and outside net house, soil and substrate temperature during 2017/2018 and 2018/2019 seasons. 

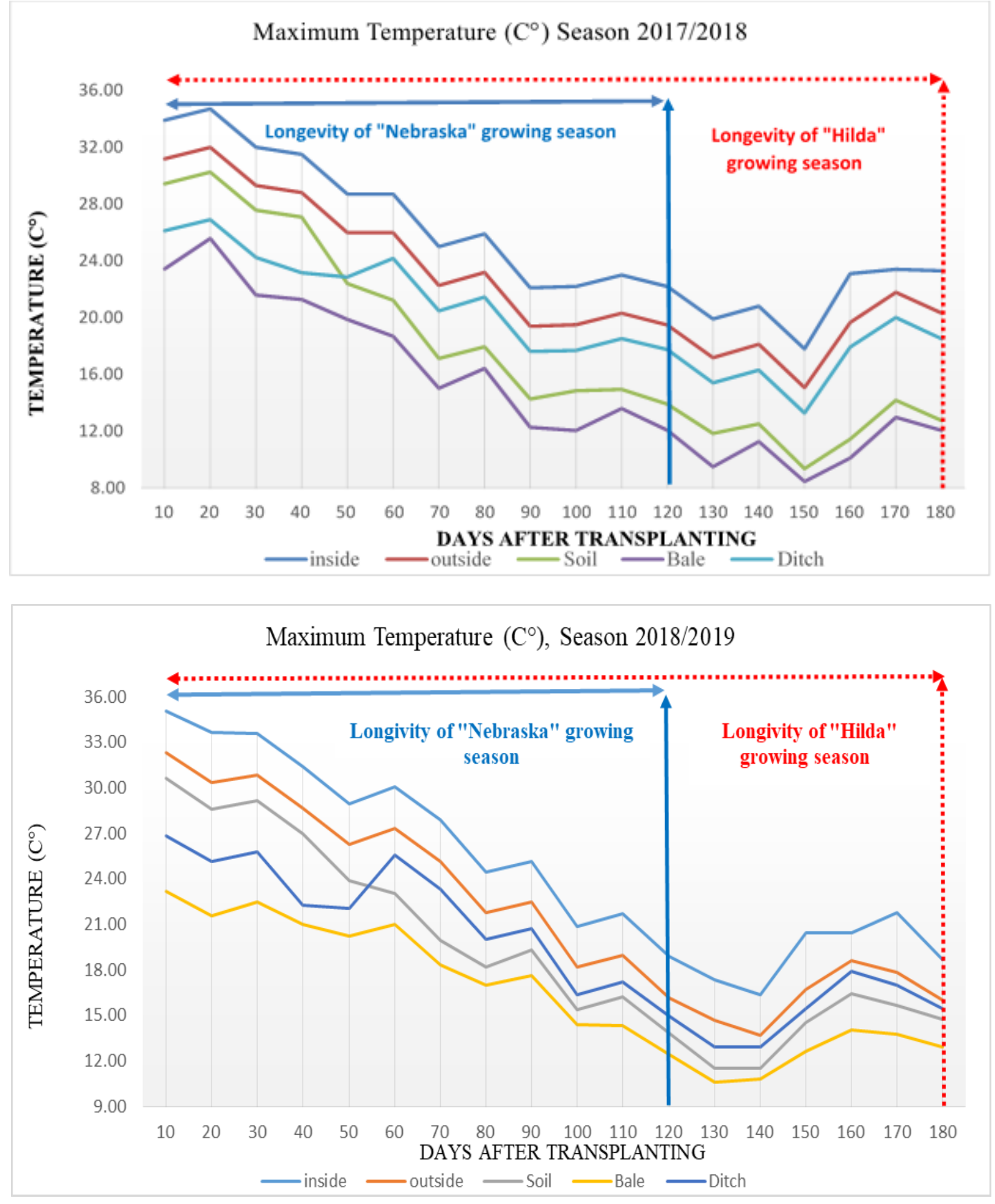

Figure 2 Maximum air temperature inside and outside net house, soil and substrate temperature during 2017/2018 and $2018 / 2019$ seasons.

The effect of using rice straw as a growing substrate (bale and ditch) compared to traditional cultivation in soil on vegetative growth characters of two types of common bean cultivars were documented at Tables $(4,5$ and 6$)$. 
Table 4 Effect of substrate types on plant length $(\mathrm{cm})$, number of leaves par plant, stem diameter $(\mathrm{cm})$ and leaf area $\left(\mathrm{cm}^{2}\right)$ during $2017 / 2018$ and $2018 / 2019$ seasons.

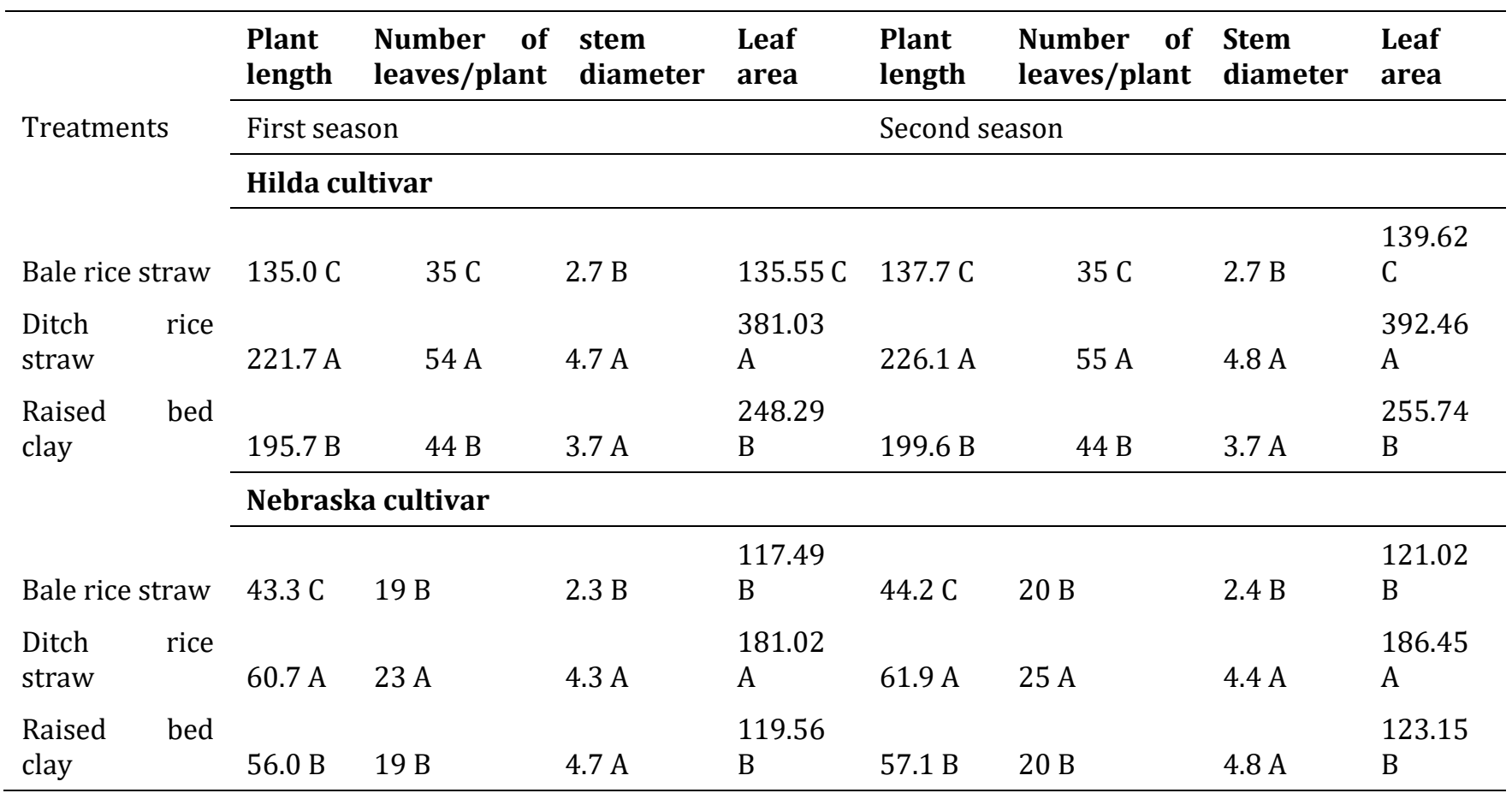

Data in Table (4) reflected the affecting characteristics of plant length, number of leaves/plant, stem diameter and leaf area as a results of using the rice straw as a growing substrate, however, as bale or in ditched image compared with traditional cultivation in soil. The highest positive effect was obtained with using ditch rice straw treatment as substrate at all studied parameters. The mentioned positive effect appeared as the highest significant values of all studied characteristics. While, the negative effect on those characters was observed with bale rice straw treatment. This negative impact reflected in the lowest significant values of all studied vegetative growth characteristics. Whereas, raised bed clay (control) treatment was replaced in second place after the treatment of ditch rice straw. This trend was found in two common bean studied cultivars (Hilda and Nebraska cultivars) and also it was true in the two tested seasons.

Table 5 Effect of substrate types on fresh weight of leaves/plant (g), stem/plant (g) and total plant (g) during $2017 / 2018$ and 2018/2019 seasons.

\begin{tabular}{|c|c|c|c|c|c|c|}
\hline \multirow{4}{*}{ Treatments } & \multicolumn{6}{|c|}{ Fresh weight } \\
\hline & $\begin{array}{l}\text { Leaves/ } \\
\text { plant }\end{array}$ & $\begin{array}{l}\text { Stem/ } \\
\text { plant }\end{array}$ & Total plant & $\begin{array}{l}\text { Leaves/ } \\
\text { plant }\end{array}$ & $\begin{array}{l}\text { Stem/ } \\
\text { plant }\end{array}$ & Total plant \\
\hline & \multicolumn{3}{|c|}{ First season } & \multicolumn{3}{|c|}{ Second season } \\
\hline & \multicolumn{6}{|c|}{ Hilda cultivar } \\
\hline Bale rice straw & $76.93 \mathrm{C}$ & $53.07 \mathrm{C}$ & $130.00 \mathrm{C}$ & $84.63 \mathrm{C}$ & $58.37 \mathrm{C}$ & $143.00 \mathrm{C}$ \\
\hline Ditch rice straw & $237.97 \mathrm{~A}$ & $108.50 \mathrm{~A}$ & $346.47 \mathrm{~A}$ & $261.76 \mathrm{~A}$ & $119.35 \mathrm{~A}$ & $381.11 \mathrm{~A}$ \\
\hline \multirow[t]{2}{*}{ Raised bed clay } & $125.07 \mathrm{~B}$ & $79.33 \mathrm{~B}$ & $204.40 \mathrm{~B}$ & $137.57 \mathrm{~B}$ & $87.27 \mathrm{~B}$ & $224.84 \mathrm{~B}$ \\
\hline & \multicolumn{6}{|c|}{ Nebraska cultivar } \\
\hline Bale rice straw & $37.57 \mathrm{C}$ & $28.37 \mathrm{C}$ & $65.93 \mathrm{C}$ & $41.32 \mathrm{C}$ & $31.20 \mathrm{C}$ & $72.53 \mathrm{C}$ \\
\hline Ditch rice straw & $91.40 \mathrm{~A}$ & $36.23 \mathrm{~A}$ & $127.63 \mathrm{~A}$ & $100.54 \mathrm{~A}$ & $39.86 \mathrm{~A}$ & $140.40 \mathrm{~A}$ \\
\hline Raised bed clay & $72.83 \mathrm{~B}$ & $31.93 \mathrm{~B}$ & $104.77 \mathrm{~B}$ & $80.12 \mathrm{~B}$ & $35.13 \mathrm{~B}$ & $115.24 \mathrm{~B}$ \\
\hline
\end{tabular}


Presented data in Tables $(5,6)$ indicated the performance of using rice straw as a growing substrate (bale and ditch) compared to traditional cultivation on both fresh and dry weight of leaves/plant, stem/plant and total plants of common bean (Hilda and Nebraska). It was noticeable that, all of the last mentioned characteristics was enhanced and significantly increased at each of the studied growing seasons by using rice straw as a substrate. Ditch rice straw significantly ranked first followed by the traditional cultivation method (raised bed clay). However, bale rice straw method was significantly ranked the last. Such results was typically obtained from the two studied cultivars.

Table 6 Effect of substrate types on dry weight of leaves/plant (g), stem/plant (g) and total plant (g) during 2017/2018 and 2018/2019 seasons.

\begin{tabular}{|c|c|c|c|c|c|c|}
\hline \multirow{4}{*}{ Treatments } & \multicolumn{6}{|c|}{ Dry weight } \\
\hline & $\begin{array}{l}\text { Leaves } \\
\text { /plant }\end{array}$ & $\begin{array}{l}\text { Stem/ } \\
\text { plant }\end{array}$ & Total plant & $\begin{array}{l}\text { Leaves } \\
\text { /plant }\end{array}$ & $\begin{array}{l}\text { Stem/ } \\
\text { plant }\end{array}$ & Total plant \\
\hline & \multicolumn{3}{|c|}{ First season } & \multicolumn{3}{|c|}{ Second season } \\
\hline & \multicolumn{6}{|c|}{ Hilda cultivar } \\
\hline Bale rice straw & $15.86 \mathrm{C}$ & $12.27 \mathrm{C}$ & $28.13 \mathrm{C}$ & $17.45 \mathrm{C}$ & $13.50 \mathrm{C}$ & $30.95 \mathrm{C}$ \\
\hline Ditch rice straw & $32.69 \mathrm{~A}$ & $23.02 \mathrm{~A}$ & $55.71 \mathrm{~A}$ & $35.96 \mathrm{~A}$ & $25.32 \mathrm{~A}$ & $61.28 \mathrm{~A}$ \\
\hline \multirow[t]{2}{*}{ Raised bed clay } & $22.81 \mathrm{~B}$ & $18.64 \mathrm{~B}$ & $41.45 \mathrm{~B}$ & $25.09 \mathrm{~B}$ & $20.51 \mathrm{~B}$ & $45.60 \mathrm{~B}$ \\
\hline & \multicolumn{6}{|c|}{ Nebraska cultivar } \\
\hline Bale rice straw & $8.85 \mathrm{C}$ & $7.58 \mathrm{C}$ & $16.42 \mathrm{C}$ & $9.73 \mathrm{C}$ & $8.34 \mathrm{C}$ & $18.06 \mathrm{C}$ \\
\hline Ditch rice straw & $21.48 \mathrm{~A}$ & $12.65 \mathrm{~A}$ & $34.13 \mathrm{~A}$ & $23.63 \mathrm{~A}$ & $13.92 \mathrm{~A}$ & $37.55 \mathrm{~A}$ \\
\hline Raised bed clay & $15.58 \mathrm{~B}$ & $10.75 \mathrm{~B}$ & $26.32 \mathrm{~B}$ & $17.14 \mathrm{~B}$ & $11.82 \mathrm{~B}$ & $28.96 \mathrm{~B}$ \\
\hline
\end{tabular}

Table 7 Effect of substrate types on dry leaf content of N. P. K (\%) during 2017/2018 and 2018/2019 seasons.

\begin{tabular}{|c|c|c|c|c|c|c|}
\hline \multirow{3}{*}{ Treatments } & $\mathbf{N}$ & $\mathbf{P}$ & $\mathbf{K}$ & $\mathbf{N}$ & $\mathbf{P}$ & $\mathbf{K}$ \\
\hline & \multicolumn{3}{|c|}{ First season } & \multicolumn{3}{|c|}{ Second season } \\
\hline & \multicolumn{6}{|c|}{ Hilda cultivar } \\
\hline Bale rice straw & $4.20 \mathrm{~B}$ & $0.57 \mathrm{~B}$ & $1.48 \mathrm{~B}$ & $4.24 \mathrm{~B}$ & $0.58 \mathrm{~B}$ & $1.49 \mathrm{~B}$ \\
\hline Ditch rice straw & $4.51 \mathrm{~B}$ & $0.96 \mathrm{~A}$ & $1.88 \mathrm{~A}$ & $4.55 \mathrm{~B}$ & $0.79 \mathrm{~A}$ & $1.90 \mathrm{~A}$ \\
\hline \multirow[t]{2}{*}{ Raised bed clay } & $5.00 \mathrm{~A}$ & $0.77 \mathrm{~A}$ & $2.17 \mathrm{~A}$ & $5.05 \mathrm{~A}$ & $0.78 \mathrm{~A}$ & $2.19 \mathrm{~A}$ \\
\hline & \multicolumn{6}{|c|}{ Nebraska cultivar } \\
\hline Bale rice straw & $3.96 \mathrm{~B}$ & $0.55 \mathrm{~B}$ & $1.40 \mathrm{~B}$ & $4.00 \mathrm{~B}$ & $0.56 \mathrm{~B}$ & $1.41 \mathrm{~B}$ \\
\hline Ditch rice straw & $4.14 \mathrm{~B}$ & $0.93 \mathrm{~A}$ & $1.80 \mathrm{~A}$ & $4.18 \mathrm{~B}$ & $0.94 \mathrm{~A}$ & $1.82 \mathrm{~A}$ \\
\hline Raised bed clay & $4.54 \mathrm{~A}$ & $0.75 \mathrm{~A}$ & $2.11 \mathrm{~A}$ & $4.59 \mathrm{~A}$ & $0.75 \mathrm{~A}$ & $2.13 \mathrm{~A}$ \\
\hline
\end{tabular}

The statically analysis presented showed the effect of the tested factor on N, P and K in leaves. Results indicated in Table (7) that cultivated common bean plants on rice straw (bale or ditch) decreased $\mathrm{N}$ content compared to cultivation in clay soil. Whereas, $\mathrm{P}$ and $\mathrm{K}$ contents were increased by cultivation on clay soil and ditch rice straw without any significant between them. These results were detected in both growing seasons regardless the tested cultivars. 
Table 8 Effect of substrate types on number of pods/plant, total yield/plant (g) and fiber content in green pods (\%) during 2017/2018 and 2018/2019 seasons.

\begin{tabular}{|c|c|c|c|c|c|c|}
\hline \multirow{3}{*}{ Treatments } & $\begin{array}{l}\text { Number of } \\
\text { pods/plant }\end{array}$ & $\begin{array}{l}\text { Total } \\
\text { yield/plant }\end{array}$ & $\begin{array}{l}\text { Fiber } \\
\text { content }\end{array}$ & $\begin{array}{l}\text { Number of } \\
\text { pods/plant }\end{array}$ & $\begin{array}{l}\text { Total } \\
\text { yield/plant }\end{array}$ & $\begin{array}{l}\text { Fiber } \\
\text { content }\end{array}$ \\
\hline & \multicolumn{3}{|l|}{ First season } & \multicolumn{3}{|c|}{ Second season } \\
\hline & \multicolumn{6}{|c|}{ Hilda cultivar } \\
\hline Bale rice straw & $129.3 \mathrm{C}$ & $776.0 \mathrm{C}$ & $10.03 \mathrm{~B}$ & $130.6 \mathrm{C}$ & $783.8 \mathrm{C}$ & $10.13 \mathrm{~B}$ \\
\hline Ditch rice straw & $180.7 \mathrm{~A}$ & $1210.5 \mathrm{~A}$ & $9.20 \mathrm{~A}$ & $182.5 \mathrm{~A}$ & $1222.6 \mathrm{~A}$ & $9.29 \mathrm{~A}$ \\
\hline \multirow[t]{2}{*}{ Raised bed clay } & $153.0 \mathrm{~B}$ & $948.6 \mathrm{~B}$ & $11.43 \mathrm{C}$ & $154.5 \mathrm{~B}$ & $958.1 \mathrm{~B}$ & $11.55 \mathrm{C}$ \\
\hline & \multicolumn{6}{|c|}{ Nebraska cultivar } \\
\hline Bale rice straw & $64 \mathrm{C}$ & $366.70 \mathrm{C}$ & $10.63 \mathrm{~B}$ & $66 \mathrm{C}$ & $374.03 \mathrm{C}$ & $10.74 \mathrm{~B}$ \\
\hline Ditch rice straw & $87 \mathrm{~A}$ & $541.47 \mathrm{~A}$ & $9.73 \mathrm{~A}$ & $89 \mathrm{~A}$ & $552.30 \mathrm{~A}$ & $9.83 \mathrm{~A}$ \\
\hline Raised bed clay & $76 \mathrm{~B}$ & $471.20 \mathrm{~B}$ & $11.73 \mathrm{C}$ & $78 \mathrm{~B}$ & $480.62 \mathrm{~B}$ & $11.85 \mathrm{C}$ \\
\hline
\end{tabular}

Table (8) show effect of using rice straw as a growing substrate (bale and ditch) compared to traditional cultivation in soil on yield (number of pods and total yield/plant) and its components (fiber content) of two common bean cultivars. Obtained data from Table (8) indicated that, the highest significant yield as number of pads/plant was recoded with using ditch rice straw treatment, followed by raised bed clay (control) treatment, respectively. When, noticed a significant reduction in those mentioned parameters with using bale rice straw. Whereas, the most effective substrate in decreasing fiber content was ditch rice straw treatment compared with other substrate tested. The last mentioned trend of results were confirmed during the two tested seasons and both cultivars.

Table 9 Effect of substrate types on water use efficiency (WUE) for common bean cultivars during 2017/2018 and 2018/2019 seasons.

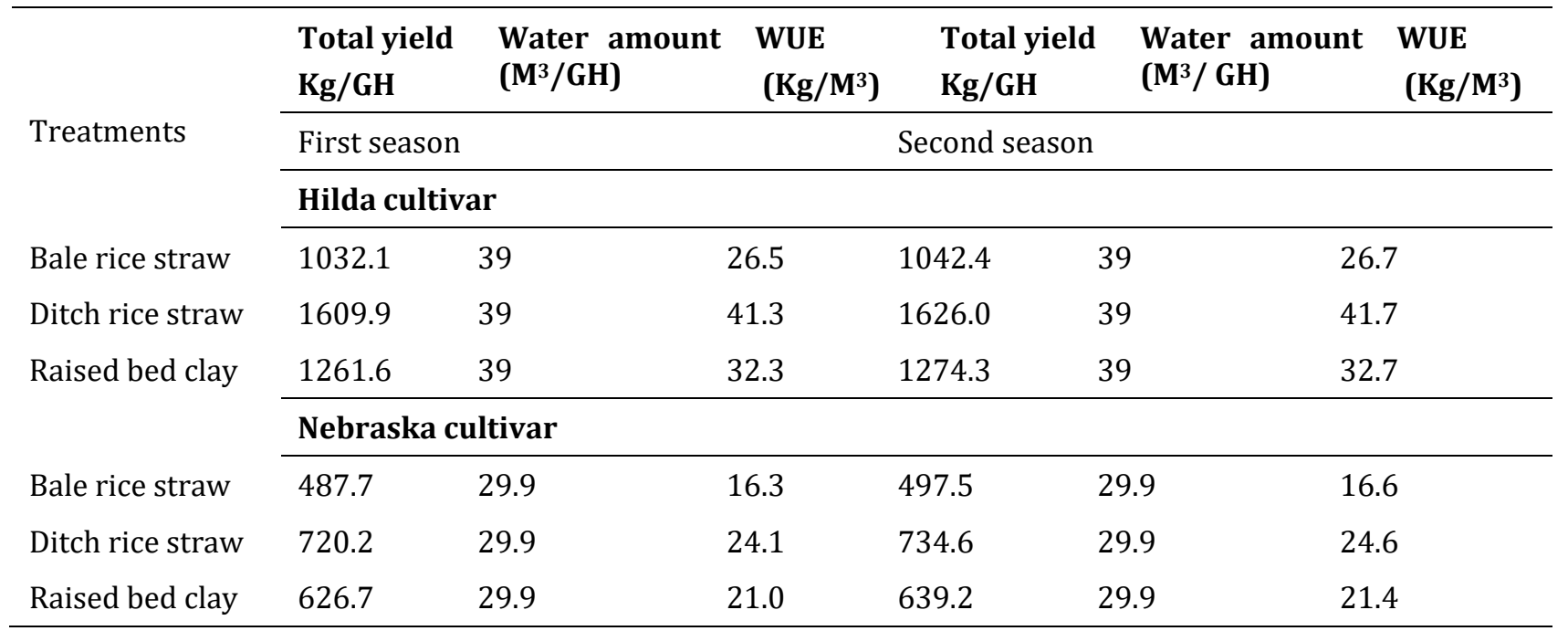

Data in Table (9) revealed that there were a significant effect for different rice straw substrate types beside the clay soil on irrigation water consumption as well as water use efficiency between both tested common bean cultivars. Generally, results stated that both cultivars are differ in the values of water use efficiency, because of the different growth behavior in both cultivars led to increase water consumption for the indeterminate cultivar compared to the determinate one. Furthermore, the different amount of total yield between indeterminate and determinate reflected basically on the water consumption and water use efficiency. On the other hand, the treatment of ditched rice straw generated the highest values of WUE for both cultivars followed by the treatment of clay soil during the two tested seasons of study. In the contrary, baled rice straw treatment gave the lowest values of WUE in both growing seasons. These results may 
be due to the effect of physical characteristics for different substrate type. The ability of substrate to holding the available water and nutrition minerals depends on the size of particles and compactness of the substrate. The suitable mix between oxygen and water as well as nutrient solution enhanced the growth and production of plants. On the other hands, common bean plant is very sensitive to increased irrigation water and that led to destroy the root system because of infection by soil borne diseases, so the ditched rice straw treatment initiated a moderated irrigation and respiration for roots system. On the contrary, baled rice straw did not gave the sufficient amount of irrigation water as well as nutrition elements for common bean plants that led do decrease the total production then WUE. The raised bed clay soil treatment take the second rank after ditched rice straw because of fertility of clay soil led to increase the total yield. These results are true in both growing seasons.

\section{Discussion}

Straw mineralization is considered a profitable wonder, since at that point $\mathrm{CO}_{2}$ is discharged, which is utilized by plants within the handle of photosynthesis. The increased $\mathrm{CO}_{2}$ concentration within the protected house causes crop yield increment. $\mathrm{CO}_{2}$ concentration within the open air is almost $350 \mathrm{ppm}$, however the effective concentration inside the greenhouses is about 900-1000 ppm [16, 17 and 18].

Obtained results from this investigation are similar to those occurred by [19] on cucumber plants, who reported that development of cucumber plants were more strong when developed in unfastened straw than within the soil.

In addition, [6] found that cucumber plants developed in rice straw bunches beneath nursery conditions appeared superior development compared with those developed in soil. Moreover, [5] expressed that strawberry plants cultivated in rice straw bale expanded the number of leaves/plant, plant length; number of shoots/plant, compared with those developed in natural soil.

The excellence of plants grown in rice straw compared to other agricultural media on basis of the high temperature of rice straw media compared to other media or soil especially during the cool seasons was explained [20]. Also, the author focused on bulk density and porosity of straw medium allowed the root system to diffuse easily in substrate, which is reflected in good water and nutrient elements for the plant. Later on, [21] clear up increments organic substrate's temperature on basis of the activity of microorganism in decomposition. High temperatures substrate of organic substrate reflected significantly on crops grown under unheated greenhouses (such like conditions of the current investigation).

Addition to the high temperature [5] and [22] added the low levels of $\mathrm{pH}$ and salinity of rice straw media for the reasons of superiority. Moreover, increasing level of $\mathrm{Co}_{2}$ and photosynthesis were reported as a main causes for the excellence of rice straw media over other tested media [16, 17 and 18]. Root temperature is thought to be one of the major variables that directly affect plant development [23] and increments abdicate [24]. Under the conditions of this investigation, rice straw media gave higher yields than other tested soil proposed superior wholesome conditions within the straw medium. The concluded trend of result is being in agreement with [25] in pepper plants.

\section{Conclusion}

It's concluded that rice straw constitutes a promptly accessible natural fabric that can be utilized in soilless greenhouse culture as a substrate since of its light weight, low cost, content of essential elements required by plants in adequate amount to fulfill edit prerequisites, and its accessibility. Also, rice straw is simpler to arrange of than such mineral substrates whose recycling causes genuine natural problems.

\section{References}

[1] Pathania A, SK Sharma and PN Sharma. (2014). Common bean. M. Singh et al. (eds.), Broadening the Genetic Base of Grain Legumes, 11-50.

[2] Bilderback, TE, SL Warren, JS, Owen Jr and JP Albano. (2005). Healthy substrates need physicals too. HortTechnology, 15(4), 747-751.

[3] Loehr RC. (1974). Agricultural waste management. Academic pree.inc. (London) L T D. 576.

[4] Xiongnian Y. (2010). Reuse of agricultural wastes and increase of income of farmers. 
[5] Abdet-Sattar MA, HA El-Marzoky and AI Mohamed. (2008). Occurrence of soilborne diseases and knot nematodes in strawberry plants grown on compacted rice straw bales compared with naturally infested soils. Journal of plant protection research, 48(2), 224-235.

[6] Abdel-Sattar MA. (2005). Using compacted rice straw bales, as growing media instead of naturally infested soil for improving cucumber production under greenhouse conditions in Egypt, 265-278.

[7] VERCON. (2007). Common bean production. Bulletin No. 1085.

[8] AOAC. (2005). Official Methods of Analysis: Association of Official Analytical Chemists.16th (Ed).Washington. DC.577-581.

[9] Abou-Hadid AF and AS El-Beltagy. (1992). Water balance under plastic house conditions in Egypt. Acta Hort, 303, 61-72.

[10] Doorenbos J and WO Pruitt. (1977). Guidelines for predicting crop water requirements. In: Irrigation and Drainage Paper No. 24, FAO, Rome, 179.

[11] Allen RG, LS Pereira, D Raes and M Smith. (1998). Crop evapotranspiration guidelines for computing crop water requirements. FAO Irrigation and drainage paper 56. Food and Agriculture Organization, Rome.

[12] Chapman HD and PF Pratt. (1961). Methods of analysis for soils, plants, and waters. Univ. of Calif., Div. Agr. Sci., Berkeley, Calif. 309.

[13] FAO. (1980). Soil and Plant Analysis. Soils Bulletin, 38, 2-250.

[14] Srinivas K, DM Hegde and GV Havangi. (1989). Irrigation Studies of Watermelon (Citrullus lanatus (Thunb) Mastum et Nackai). Irrig. Sci, 10, 293-301.

[15] SAS Institute. (2005). The SAS system for Microsoft Windows. Release 9. 1. SAS Inst., Cary, NC.

[16] Elings A, E Meinen, J Campen, C Stanghellini and A Gelder. (2007). The photosynthesis response of tomato to air circulation. Acta Horticulture, No.761, 77-84.

[17] Hao X, Q Wang and S Khosla. (2008). Responses of greenhouse tomatoes to summer CO2 enrichment. Acta Horticulture, No. 797, 241-246.

[18] Stanghellini C, FLK Kempkes and L Incrocci. (2009). Carbon dioxide fertilization in Mediterranean greenhouses: when and how is it economical?. Acta Horticulture, 807, 135-142.

[19] Gaspervicute G. (1977). Using straw for cucumber growing in polyethylene houses. Horticulture Abstiract, 48, $550-559$.

[20] Olympious CM. (1992). Soilless media under protected cultivation rock wool, peat, perlite and other substrates. Acta Horticulture, 401, 443-451.

[21] Tzortzakis G and D Economakis. (2015). Shredded maize stems as an alternative substrate substrate: effect on growth, flowering and yield of tomato in soilless culture. Journal of Vegetable Science, 11(2), 57-70.

[22] Mohamed AI. (2010). Comparative studies on disease occurrence of some vegetables grown on compacted rice straw bales and natural soil. Master of Science, Suez Canal University Faculty of Agriculture. Botany Department.

[23] Ikeda H and T Osawa. (1984). Lettuce growth as influenced by N source and temperature of the nutrient solution. International Society for Soilless Culture. Proceedings of 6th International Congress on soilless culture, 273-284.

[24] Moss GI. (1983). Root-zone warming as a means to save energy in the production of greenhouse crops in Australia. Acta Horticulture, 133, 31-38.

[25] Padem H and R Alan. (1994). The effect of some substrates on yield and chemical composition of pepper under greenhouse conditions. Acta Horticulturae, 366, 445-451.

\section{How to cite this article}

Ahmed MS, Moursy FS and Sadek II. (2020). Evaluating the validity of rice straw as a suitable agricultural substrate for common bean plants under greenhouse condition. GSC Advanced Research and Reviews, 2(1), 10-20. 